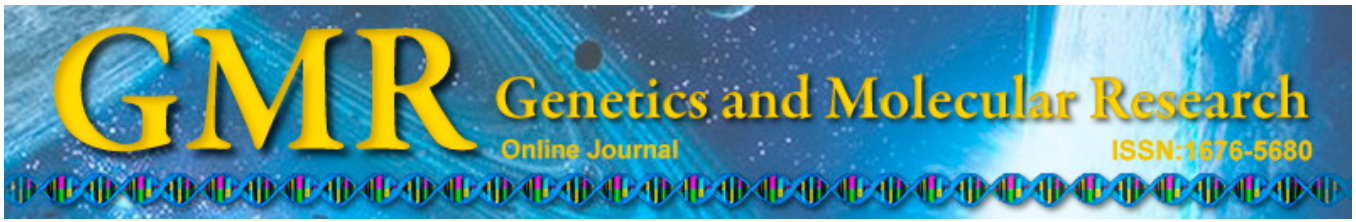

\title{
Calpain-10 gene polymorphisms and risk of type 2 diabetes mellitus in Mexican mestizos
}

\author{
V.J. Picos-Cárdenas ${ }^{1,2 *}$, E. Sáinz-González ${ }^{2,3 *}$, A. Miliar-García ${ }^{3}$, \\ A. Romero-Zazueta ${ }^{4}$, R. Quintero-Osuna ${ }^{5}$, E. Leal-Ugarte ${ }^{6}$, \\ V. Peralta-Leal ${ }^{6}$ and J.P. Meza-Espinoza ${ }^{6}$ \\ ${ }^{1}$ Laboratorio de Genética Humana, Facultad de Medicina, \\ Universidad Autónoma de Sinaloa, Culiacán, \\ Sinaloa, México \\ ${ }^{2}$ Laboratorio de Genética y Metabolismo, Hospital General de Culiacán, \\ Culiacán, Sinaloa, México \\ ${ }^{3}$ Laboratorio de Biología Molecular, \\ Sección de Estudios de Posgrado e Investigación, \\ Escuela Superior de Medicina, Instituto Politécnico Nacional, D.F., México \\ ${ }^{4}$ Servicio de Endocrinología, Hospital General de Culiacán, Culiacán, \\ Sinaloa, México \\ ${ }^{5}$ Módulo DiabetIMSS Clínica 35, Instituto Mexicano del Seguro Social, \\ Culiacán, Sinaloa, México \\ ${ }^{6}$ Facultad de Medicina e Ingeniería en Sistemas Computacionales de Matamoros, \\ Universidad Autónoma de Tamaulipas, Matamoros, Tamaulipas, México \\ *These authors contributed equally to this study. \\ Corresponding author: J.P. Meza-Espinoza \\ E-mail: sirol1073@yahoo.com.mx/pmeza@uat.edu.mx
}

Genet. Mol. Res. 14 (1): 2205-2215 (2015)

Received January 15, 2014

Accepted August 8, 2014

Published March 27, 2015

DOI http://dx.doi.org/10.4238/2015.March.27.6

ABSTRACT. The calpain-10 gene is expressed primarily in tissues important in glucose metabolism; thus, some of its polymorphisms have been associated with type 2 diabetes. In this study, we examined the association between the calpain-10 single-nucleotide polymorphism (SNP)-43, SNP19, and SNP-63 and type 2 diabetes in Mexican mestizos. We included 211 patients and 152 non-diabetic subjects. Polymerase chain reaction was used 
to identify alleles. We compared allele, genotype, haplotype, and diplotype frequencies between both groups and used the chi-square test to calculate the risk. The allele frequency of SNP-43 allele 1 was $70 \%$ in controls and $72 \%$ in patients; the GG, GA, and AA genotype frequencies were 48.7, 42.8, and $8.5 \%$ in controls and $51.2,41.7$, and $7.1 \%$ in patients, respectively. For SNP19 , the prevalence of allele $1(2 \mathrm{R})$ was $32 \%$ in controls and $39 \%$ in patients. In controls, homozygosity $(2 \mathrm{R} / 2 \mathrm{R})$ was $10.5 \%$, heterozygosity was $42.8 \%$, and $3 \mathrm{R} / 3 \mathrm{R}$ was $46.7 \%$; in cases, these values were $13.3,50.7$, and $36.0 \%$, respectively. For SNP-63, the frequency of allele 1 was $87 \%$ in controls and $83 \%$ in patients; genotype frequencies in controls were $75.7 \%$ (CC), $23 \%$ (CT), and $1.3 \%$ (TT), and were $69.7,27.5$, and $2.8 \%$, respectively for the cases. Genotype distributions were consistent with Hardy-Weinberg equilibrium. No significant intergroup differences for allele, genotype, haplotype, or diplotype frequencies were observed. We found no association between these polymorphisms and diabetes. However, our sample size was small, so the role of calpain-10 risk alleles should be further examined.

Key words: $C A P N 10$ polymorphisms; Mexican mestizo; Type 2 diabetes

\section{INTRODUCTION}

Type 2 diabetes mellitus (T2DM) is a systemic, chronic, and progressive disease characterized by deficiency in production or action of insulin, which leads to hyperglycemia. The current International Diabetes Federation estimates that approximately 371 million people have diabetes worldwide, and this figure is likely to increase to 500 million by the year 2030. T2DM is among the principal causes of death due to premature cardiovascular disease, vascular-cerebral disorder, and renal failure. In 2012, there were approximately 4.8 million deaths from diabetes worldwide, with nearly $80 \%$ occurring in underdeveloped countries (International Diabetes Federation, 2013). In Mexico, the prevalence of T2DM is approximately $14.42 \%$, accounting for 7.3 million patients (Villalpando et al., 2010). The etiology of T2DM is complex and involves both genetic and environmental factors. Among the $>40$ genes related to T2DM (OMIM, 2013), the calpain-10 (CAPN10) gene was initially associated with this disease in Mexican-Americans. This gene consists of 15 exons and produces a 672-amino acid protein (Horikawa et al., 2000). CAPN10 has been implicated in insulin receptor regulation and adipocyte differentiation (Patel and Lane, 1999) and is expressed primarily in tissues important in glucose metabolism, suggesting that it affects insulin secretion and action as well as liver glucose synthesis (Lynn et al., 2002). Single-nucleotide polymorphisms (SNPs) or haplotypes formed by SNP-43 (rs3792267; G4852A), SNP-19 [(rs3842570; 32 base pairs (bp) ins/del], and SNP-63 (rs5030952; C16378T) of this gene have been widely studied in relation to T2DM risk (Horikawa et al., 2000; Evans et al., 2001; Tsai et al., 2001; Fingerlin et al., 2002; Garant et al., 2002; Malecki et al., 2002; Orho-Melander et al., 2002; Rasmussen et al., 2002; Horikawa et al., 2003; del Bosque-Plata et al., 2004; Wu et al., 2005; Kang et al., 2006; Tsuchiya et al., 2006; Chen et al., 2005, 2007; Kifagi et al., 2008; Adak et al., 2010; Ezzidi et al., 2010; Bodhini et al., 2011). In this study, we analyzed whether an association exists between the CAPN10 SNP-43, SNP-19, and SNP-63 polymorphisms and T2DM in a Mexican mestizo population. 


\section{MATERIAL AND METHODS}

\section{Subjects}

We analyzed 211 unrelated adult T2DM patients, diagnosed according to American Diabetes Association criteria (2013), including 143 women (68\%) and 68 men (32\%), and 152 unrelated controls with no family history of T2DM in first-degree relatives, including 103 women (68\%) and 49 men (32\%); all individuals were Mexican mestizos residing in the same region. Patients were enrolled at the Endocrinology Service of the General Hospital and at the Clinic \#35 of the Mexican Institute of Social Security in Culiacán, Sinaloa, México. Controls were subjects over 40 years of age with no medical history of T2DM and normal fasting glycemia $(80-110 \mathrm{mg} / \mathrm{dL})$. Both patients and controls signed informed consent to participate in this study. The patients' mean age was 58.5 years, while it was 50.4 years in controls. The mean fasting plasma glucose level was $147.77 \pm 66.13 \mathrm{mg} / \mathrm{dL}$ in patients and $92.85 \pm 12.52 \mathrm{mg} / \mathrm{dL}$ in controls. Mean body mass index (BMI) of patients and controls was $31.08 \pm 5.56 \mathrm{~kg} / \mathrm{m}^{2}$ and $28.47 \pm 5.17 \mathrm{~kg} / \mathrm{m}^{2}$, respectively; $46 \%$ of the patients had a BMI of $30-40 \mathrm{~kg} / \mathrm{m}^{2}$, whereas $27.9 \%$ of the controls were in this range. Mean concentrations of cholesterol and triglycerides in patients were $206.9 \mathrm{mg} / \mathrm{dL}$ and $173.04 \mathrm{mg} / \mathrm{dL}$, respectively; in controls, these values were $199.29 \mathrm{mg} / \mathrm{dL}$ and $140.4 \mathrm{mg} / \mathrm{dL}$. This study was approved by the ethics committee of each participating institution.

\section{Genotyping}

\section{SNP-43 and SNP-63}

To identify the alleles of SNP-43 and SNP-63, we carried out real-time polymerase chain reaction (PCR). Primers for the Hybridization Probes (HybProbes) assays were obtained from TIB MOLBIOL, LLC (Adelphia, NJ, USA). For SNP-43, we used the primers 5'-TCCA TCCCAAGGGCTGTT-3' and 5'-TCTGTAGCACCCCAAATCG-3', and the acceptor 5'-GAAGTAAGGCATTTGAAGGTGA-FL-3' and donor 5'-LCR640-GCTAAGCCTTGAC TTGGTGAGGATGAGG-PH-3' probes; for SNP-63, we used the primers 5'-CCTGGTCACT GGATGTTG-3' and 5'-GGCTGGAGTTTGGAGAAGTT-3', and 5'-GGGTGGAGCGAGGG GT-FL-3' as the acceptor and 5'-LCR640-GGCCGCGTCTGTGCAGGC-PH-3' as the donor. Real-time PCR was performed in a LightCycler (Roche; Basel, Switzerland) according to manufacturer instructions. Standard $10-\mu \mathrm{L}$ reaction mixtures contained 2-4 mM MgCl, $1 \mathrm{X}$ LightCycler FastStart DNA Master Hybridization Probes master mix, $0.25 \mu \mathrm{M}$ of each primer, $0.2 \mu \mathrm{M}$ of each probe, $0.01 \mathrm{U} / \mu \mathrm{L}$ Escherichia coli uracil N-glycosylase (UNG, Roche), and $100 \mathrm{ng}$ genomic DNA. The reaction was initiated with a 5-min hold at room temperature for contamination control by UNG and $10 \mathrm{~min}$ at $95^{\circ} \mathrm{C}$ to activate the polymerase. Thermal cycling was performed at $95^{\circ} \mathrm{C}$ for $10 \mathrm{~s}, 55^{\circ} \mathrm{C}$ for $20 \mathrm{~s}$, and $72^{\circ} \mathrm{C}$ for $20 \mathrm{~s}$ for 40 cycles. The transition rate between all steps was $20^{\circ} \mathrm{C} / \mathrm{s}$ (Figures 1 and 2).

\section{SNP-19}

This polymorphism is a 32-bp insertion/deletion. To identify the polymorphism, we carried out simple PCR using the following primers: 5'-GTTTGGTTCTCTTCAGCGTGGA 
G-3' (sense) and 5'- CATGAACCCTGGCAGGGTCTAAG-3' (antisense). The reaction was carried out in a total volume of $20 \mu \mathrm{L}$ containing $1 \mathrm{X}$ PCR buffer, 5\% dimethyl sulfoxide, 200 $\mu \mathrm{M}$ of each dNTP, $1.5 \mathrm{mM} \mathrm{MgCl}_{2}, 2.0 \mathrm{U}$ Taq Platinum DNA polymerase (Invitrogen, Carlsbad, CA, USA), $10 \mathrm{pM}$ of each primer, and $50 \mathrm{ng}$ genomic DNA. Amplification conditions were as follows: initial denaturation at $96^{\circ} \mathrm{C}$ for $12 \mathrm{~min}, 35$ cycles at $96^{\circ} \mathrm{C}$ for $30 \mathrm{~s}, 60^{\circ} \mathrm{C}$ for $30 \mathrm{~s}$, and $72^{\circ} \mathrm{C}$ for $30 \mathrm{~s}$, followed by final extension at $72^{\circ} \mathrm{C}$ for $10 \mathrm{~min}$ (Haddad et al., 2002). Thus, allele 1, which bears 2 32-bp repeats (2R), yielded a fragment of $155 \mathrm{bp}$; allele 2, with 3 repeats (3R), was a 187-bp fragment (Figure 3).

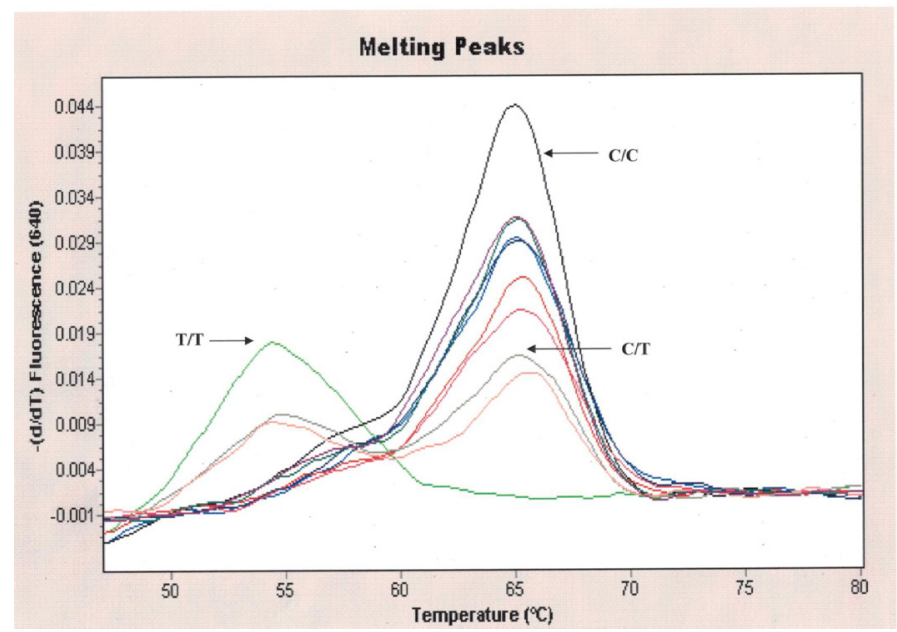

Figure 1. Graphic of a real-time PCR showing results for CAPN10 SNP-63. C/C: Wild homozygote (only one curve at $65^{\circ} \mathrm{C}$ ), C/T: Heterozygote (two curves: at $54^{\circ} \mathrm{C}$ and $65^{\circ} \mathrm{C}$ ), T/T: Polymorphic homozygote (one curve at $54^{\circ} \mathrm{C}$ ).

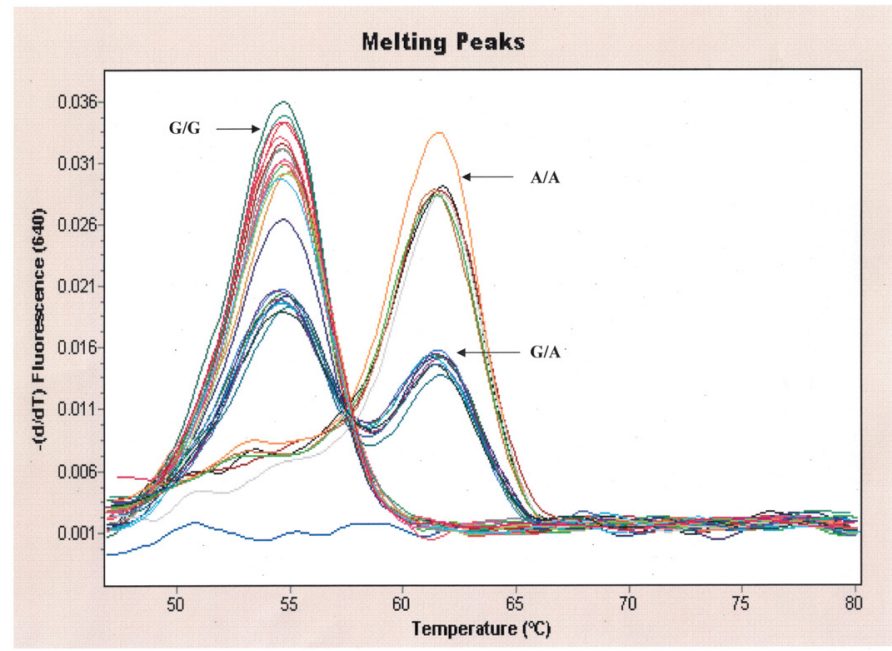

Figure 2. Graphic of a real-time PCR showing results for CAPN10 SNP-43. G/G: Wild homozygote (only one curve at $55^{\circ} \mathrm{C}$ ), G/A: Heterozygote (two curves; at $55^{\circ} \mathrm{C}$ and $61^{\circ} \mathrm{C}$ ), A/A: Polymorphic homozygote (one curve at $61^{\circ} \mathrm{C}$ ). 


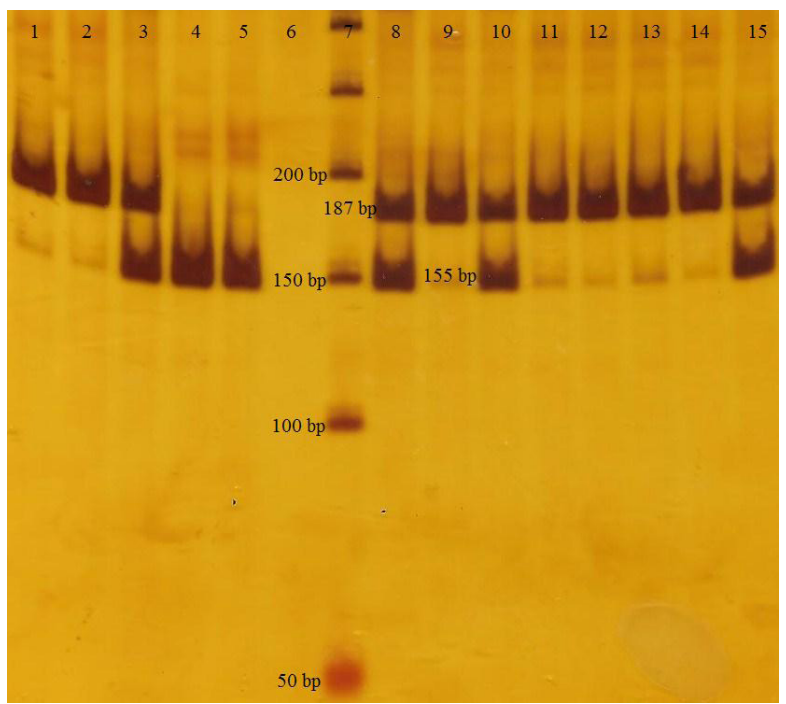

Figure 3. Polyacrylamide gel showing results for $C A P N 10$ SNP-19 in some individuals; $2 \mathrm{R}$ allele is visualized as a fragment of $155 \mathrm{bp}$ and $3 \mathrm{R}$ allele is observed as a fragment of $187 \mathrm{bp}$. Lanes 1, 2, 9, 11, 12, 13, and 14: 3R/3R genotype. Lanes 3, 8, 10, and 15:2R/3R genotype: Lanes 4 and 5:2R/2R genotype. Lane 7: 50-bp marker.

\section{Statistical analysis}

Clinical characteristics (BMI, cholesterol, and triglycerides) between cases and controls were analyzed using the Student $t$-test. Hardy-Weinberg equilibrium was evaluated by Fisher's exact test. Comparison of allele and genotype frequencies between groups was carried out using the chi-square test, and risk for T2DM was calculated as the odds ratio and $95 \%$ confidence intervals (OR; 95\% CI). Moreover, haplotype estimation was conducted using the Hapstat 3.0 software using the genotypes, and expected frequencies of diplotype were estimated according to the Hardy-Weinberg principle. Next, evaluation of risk for haplotypes and diplotypes was calculated (OR; 95\%CI). Allele 1 was taken as the reference and the level of significance was defined as $\mathrm{P} \leq 0.05$.

\section{RESULTS}

BMI and triglycerides were significantly higher in patients than in controls $(31.08 \pm$ $5.56 \mathrm{~kg} / \mathrm{m}^{2}$ vs $28.47 \pm 5.17 \mathrm{~kg} / \mathrm{m}^{2} ; \mathrm{P}<0.001$ and $173.04 \mathrm{mg} / \mathrm{dL}$ vs $140.4 \mathrm{mg} / \mathrm{dL} ; \mathrm{P}=0.012$, respectively), but there were no significant differences in cholesterol concentration $(\mathrm{P}=0.101)$. Allele and genotype frequencies of the 3 polymorphisms analyzed are summarized in Table 1. All were consistent with Hardy-Weinberg equilibrium ( $\mathrm{P}=1.0$ for SNP-43 and SNP-63, $\mathrm{P}$ $=0.85$ for SNP-19). SNP-43 genotype frequencies were 48.7, 42.8, and 8.5\% in controls and $51.2,41.7$, and $7.1 \%$ in patients for GG, GA, and AA, respectively. For SNP-19, in controls, the homozygote $2 \mathrm{R} / 2 \mathrm{R}$ was observed in $10.5 \%$ of subjects, heterozygote $2 \mathrm{R} / 3 \mathrm{R}$ was observed in $42.8 \%$ of subjects, and the genotype $3 \mathrm{R} / 3 \mathrm{R}$ was observed in $46.7 \%$ of subjects, while in cases, these genotypes were detected in $13.3,50.7$, and $36.0 \%$ of subjects, respectively. For SNP-63, the genotype (CC, CT, and TT) distribution was $75.7,23$, and $1.3 \%$ in controls and 
$69.7,27.5$, and $2.8 \%$ in patients, respectively. Overall, allele or genotype frequencies did not vary significantly between the two groups (Table 1). Comparison between patients with BMI $<30 \mathrm{~kg} / \mathrm{m}^{2}$ vs patients with BMI $\geq 30 \mathrm{~kg} / \mathrm{m}^{2}$ revealed no significant differences in allele frequencies $(\mathrm{P}=0.81$ for SNP-43, $\mathrm{P}=0.49$ for SNP-19, and $\mathrm{P}=0.34$ for SNP-63). Similarly, there was no evidence of an association between any haplotype or diplotype with T2DM risk (Table 2).

Table 1. Genotype and allele frequencies for SNP-43, SNP-19, and SNP-63 polymorphisms in patients with type 2 diabetes mellitus and controls.

\begin{tabular}{|c|c|c|c|c|}
\hline & Controls $\mathrm{N}=152$ & Cases $\mathrm{N}=211$ & OR $(95 \% \mathrm{CI})$ & *P value \\
\hline \multicolumn{5}{|l|}{ SNP-43 } \\
\hline $\mathrm{G} / \mathrm{G}$ & 74 & 108 & Reference & \\
\hline $\mathrm{G} / \mathrm{A}$ & 65 & 88 & $0.93(0.60-1.44)$ & 0.74 \\
\hline $\mathrm{A} / \mathrm{A}$ & 13 & 15 & $0.79(0.36-1.78)$ & 0.56 \\
\hline G & 0.70 & 0.72 & Reference & \\
\hline A & 0.30 & 0.28 & $0.91(0.66-1.26)$ & 0.56 \\
\hline \multicolumn{5}{|l|}{ SNP-19 } \\
\hline $2 \mathrm{R} / 2 \mathrm{R}$ & 16 & 28 & Reference & \\
\hline $2 \mathrm{R} / 3 \mathrm{R}$ & 65 & 107 & $0.94(0.47-1.87)$ & 0.86 \\
\hline $3 R / 3 R$ & 71 & 76 & $0.61(0.31-1.23)$ & 0.16 \\
\hline $2 \mathrm{R}$ & 0.32 & 0.39 & Reference & \\
\hline $3 \mathrm{R}$ & 0.68 & 0.61 & $0.75(0.55-1.02)$ & 0.06 \\
\hline \multicolumn{5}{|l|}{ SNP-63 } \\
\hline $\mathrm{C} / \mathrm{C}$ & 115 & 147 & Reference & \\
\hline $\mathrm{C} / \mathrm{T}$ & 35 & 58 & $1.30(0.80-2.11)$ & 0.29 \\
\hline $\mathrm{T} / \mathrm{T}$ & 2 & 6 & $2.35(0.42-17.2)$ & $0.25 * *$ \\
\hline $\mathrm{C}$ & 0.87 & 0.83 & Reference & \\
\hline $\mathrm{T}$ & 0.13 & 0.17 & $1.35(0.89-2.06)$ & 0.16 \\
\hline
\end{tabular}

${ }^{*}$ Chi-square test. ${ }^{* *}$ Fisher exact test.

Table 2. Haplotype and diplotype frequencies estimated for SNP-43, SNP 19, and SNP-63 polymorphisms in cases and controls.

\begin{tabular}{|c|c|c|c|c|}
\hline Haplotype & Controls $(\mathrm{N}=304)$ & Cases $(\mathrm{N}=422)$ & OR $(95 \% \mathrm{CI})$ & $* * \mathrm{P}$ value \\
\hline $121 *$ & $0.3536(107)$ & $0.3511(148)$ & Reference & \\
\hline 122 & $0.0260(8)$ & $0.0022(1)$ & $0.09(0.01-0.73)$ & $0.006^{+}$ \\
\hline 111 & $0.2165(66)$ & $0.2080(88)$ & $0.96(0.64-1.45)$ & 0.86 \\
\hline 112 & $0.1076(33)$ & $0.1608(68)$ & $1.49(0.92-2.42)$ & 0.11 \\
\hline 221 & $0.2904(88)$ & 0.2587 (109) & $0.90(0.62-1.30)$ & 0.56 \\
\hline 211 & $0.0058(2)$ & $0.0121(5)$ & $1.81(0.34-9.49)$ & $0.70^{+}$ \\
\hline 222 & 0 & $0.0071(3)$ & ND & ND \\
\hline Diplotype & $(\mathrm{N}=152)$ & $(\mathrm{N}=211)$ & & \\
\hline $121 / 221 *$ & $0.2054(31)$ & $0.1817(38)$ & Reference & \\
\hline $121 / 121$ & $0.1250(19)$ & $0.1233(26)$ & $1.12(0.52-2.38)$ & 0.78 \\
\hline $121 / 111$ & $0.1531(23)$ & $0.1461(31)$ & $1.10(0.54-2.26)$ & 0.80 \\
\hline $121 / 112$ & $0.0761(12)$ & $0.1129(24)$ & $1.63(0.71-3.78)$ & 0.25 \\
\hline $111 / 221$ & 0.1257 (19) & $0.1076(23)$ & $0.99(0.46-2.14)$ & 0.97 \\
\hline $111 / 111$ & $0.0469(7)$ & $0.0433(9)$ & $1.05(0.35-3.14)$ & 0.93 \\
\hline $111 / 112$ & $0.0466(7)$ & $0.0669(14)$ & $1.63(0.59-4.54)$ & 0.35 \\
\hline $112 / 221$ & $0.0625(10)$ & $0.0832(18)$ & $1.47(0.59-3.64)$ & 0.41 \\
\hline $221 / 221$ & $0.0843(13)$ & $0.0669(14)$ & $0.88(0.36-2.14)$ & 0.78 \\
\hline Others & $0.0744(11)$ & $0.0681(14)$ & $1.04(0.41-2.61)$ & 0.94 \\
\hline
\end{tabular}

*Haplotypes and diplotypes more common were took as reference. ${ }^{* *}$ Chi square test. ${ }^{+}$Fisher Exact test. ND $=$Not determined. 


\section{DISCUSSION}

Various studies conducted worldwide have reported an association between the CAPN10 gene polymorphisms and T2DM risk, but other studies have reported conflicting results (Horikawa et al., 2000; Evans et al., 2001; Tsai et al., 2001; Fingerlin et al., 2002; Garant et al., 2002; Malecki et al., 2002; Orho-Melander et al., 2002; Rasmussen et al., 2002; Horikawa et al., 2003; del Bosque-Plata et al., 2004; Wu et al., 2005; Kang et al., 2006; Tsuchiya et al., 2006; Chen et al., 2005, 2007; Kifagi et al., 2008; Adak et al., 2010; Ezzidi et al., 2010; Bodhini et al., 2011). Allele frequencies of CAPN10 polymorphisms vary according to the sample analyzed. Lynn et al. (2002) reported a prevalence of 79, 37, and $88 \%$ for SNP-43, SNP-19, and SNP-63, respectively, in British subjects without diabetes. Shima et al. (2003) found frequencies of $95.5,37.6$, and $73.4 \%$ for these polymorphisms in Japanese T2DM patients, whereas Sáez et al. (2008) observed frequencies of 74, 36, and 95\%, respectively, in a random Spanish sample. The frequency of the SNP-43 G allele in our patients was similar to values reported in Mexican (del Bosque-Plata et al., 2004) and European populations (Evans et al., 2001; Fingerlin et al., 2002; Malecki et al., 2002; Orho-Melander et al., 2002; Rasmussen et al., 2002), but differed from those found in Japanese (Horikawa et al., 2003; Shima et al., 2003), Korean (Kang et al., 2006), Chinese (Wu et al., 2005; Chen et al., 2007), Indian (Adak et al., 2010; Bodhini et al., 2011), Samoan (Tsai et al., 2001), and African patients (Garant et al., 2002; Chen et al., 2005; Ezzidi et al., 2010) (Table 3). The genotype and allele frequencies of SNP-43 showed no significant differences between cases and controls in our analysis. This observation agrees with those of previous studies (Evans et al., 2001; Tsai et al., 2001; Fingerlin et al., 2002; Malecki et al., 2002; Rasmussen et al., 2002; Horikawa et al., 2003; del Bosque-Plata et al., 2004; Wu et al., 2005; Kang et al., 2006; Chen et al., 2005, 2007; Adak et al., 2010; Ezzidi et al., 2010; Bodhini et al., 2011), but differs from the results of others. For example, Garant et al. (2002) found an association of the GG genotype to T2DM [OR $=1.38$ (1.04-1.83); $\mathrm{P}=0.03$ ] in African-Americans, while Orho-Melander et al. (2002) reported an association between the $\mathrm{G}$ allele and an increased risk of T2DM [OR $=1.36$ (1.07-1.73); $\mathrm{P}=$ 0.011] in a Finnish population. In contrast, Kifagi et al. (2008) found an association between the A allele and risk of T2DM in Tunisians $(\mathrm{OR}=1.86)$.

For SNP-19, we did not observe significant intergroup differences in allele and genotype frequencies, which was similar to the results of other studies (Tsai et al., 2001; Fingerlin et al., 2002; Malecki et al., 2002; Orho-Melander et al., 2002; Rasmussen et al., 2002; Horikawa et al., 2003; del Bosque-Plata et al., 2004; Wu et al., 2005; Kang et al., 2006; Chen et al., 2005, 2007; Adak et al., 2010; Bodhini et al., 2011). An association between the 2R allele with T2DM was documented in a single study of Tunisians (Arab) $[\mathrm{OR}=1.28$ (1.11-1.47); $\mathrm{P}=$ 0.0005] (Ezzidi et al., 2010). In our study, the prevalence of the $2 \mathrm{R}$ allele in patients was $39 \%$, which was also observed by del Bosque-Plata et al. (2004) in another Mexican sample, and is similar to that reported in Scandinavian (Orho-Melander et al., 2002; Rasmussen et al., 2002), Japanese (Horikawa et al., 2003), Southern Chinese (Wu et al., 2005), and Korean patients (Kang et al., 2006), but differed from that in Samoan (Tsai et al., 2001), Polish (Malecki et al., 2002), Finnish (Fingerlin et al., 2002), West African (Chen et al., 2005), Northern Chinese (Chen et al., 2007), Tunisian (Ezzidi et al., 2010), and Indian patients (Adak et al., 2010; Bodhini et al., 2011). With respect to SNP-63, allele and genotype frequencies showed no differences between groups and were thus concordant with the results of most previous studies (Tsai et al., 2001; Fingerlin et al., 2002; Malecki et al., 2002; Rasmussen et al., 2002; Horikawa et 
al., 2003; del Bosque-Plata et al., 2004; Wu et al., 2005; Kang et al., 2006; Chen et al., 2007; Ezzidi et al., 2010; Bodhini et al., 2011), but disagreed with the results of Orho-Melander et al. (2002) and Adak et al. (2010), who reported that the T allele is associated with T2DM risk in Finns $[\mathrm{OR}=1.65(1.12-2.42) ; \mathrm{P}=0.01]$ and Eastern Indians $[\mathrm{OR}=3.74$ (1.44-9.69); $\mathrm{P}=$ $0.003]$, respectively. Although there were significant differences $(\mathrm{P}=0.16)$ in our study, the $\mathrm{T}$ allele showed an OR of $1.35(0.89-2.06)$.

\begin{tabular}{|c|c|c|c|c|c|c|}
\hline Population & $\mathrm{N} 1$ and N2 & $\mathrm{N} 1(\%)$ & $\mathrm{N} 2(\%)$ & OR $(95 \% \mathrm{CI})$ & $\mathrm{P}$ & Reference \\
\hline British & $\begin{array}{l}222 \\
212\end{array}$ & 73 & 72 & $0.95(0.70-1.28)$ & $0.79^{+}$ & $($Evans et al., 2001)a \\
\hline Samoan & $\begin{array}{r}172 \\
96\end{array}$ & $\begin{array}{l}91.4 \\
32.6 \\
85.3\end{array}$ & $\begin{array}{r}91.1 \\
37 \\
83.7\end{array}$ & $\begin{array}{l}0.92(0.49-1.73) \\
1.21(0.83-1.76) \\
0.88(0.54-1.45)\end{array}$ & $\begin{array}{l}0.92^{+} \\
0.36^{+} \\
0.72^{+}\end{array}$ & (Tsai et al., 2002) \\
\hline African-American & $\begin{array}{r}269 \\
1159\end{array}$ & 90 & 87.2 & $0.76(0.56-1.03)$ & $0.09^{+}$ & $\left(\right.$Garant et al., 2002) ${ }^{\mathrm{a}}$ \\
\hline Polish & $\begin{array}{l}229 \\
148\end{array}$ & $\begin{array}{l}73.1 \\
34.3 \\
92.8\end{array}$ & $\begin{array}{l}69.3 \\
35.1 \\
90.9\end{array}$ & $\begin{array}{l}0.83(0.60-1.14) \\
1.04(0.76-1.41) \\
0.77(0.46-1.32)\end{array}$ & $\begin{array}{l}0.24 * \\
0.81 * \\
0.34 *\end{array}$ & (Malecki et al., 2002) \\
\hline Finnish & $\begin{array}{l}526 \\
408\end{array}$ & $\begin{array}{l}74 \\
45 \\
88\end{array}$ & $\begin{array}{l}75 \\
42 \\
88\end{array}$ & $\begin{array}{l}1.06(0.86-1.30) \\
0.89(0.74-1.07) \\
1.00(0.75-1.32)\end{array}$ & $\begin{array}{l}0.65^{+} \\
0.22^{+} \\
1.0^{+}\end{array}$ & (Fingerlin et al., 2002) \\
\hline Finnish & $\begin{array}{l}395 \\
298\end{array}$ & $\begin{array}{l}75.5 \\
43.5 \\
88.9\end{array}$ & $\begin{array}{l}69.4 \\
41.6 \\
92.9\end{array}$ & $\begin{array}{l}0.73(0.58-0.94) \\
0.92(0.75-1.15) \\
1.65(1.13-2.43)\end{array}$ & $\begin{array}{l}0.011^{+} \\
0.51^{+} \\
0.01^{+}\end{array}$ & (Orho-Melander et al., 2002)** \\
\hline Scandinavian & 409 & 73 & 72 & $0.96(0.74-1.26)$ & $0.79 *$ & (Rasmussen et al., 2002) \\
\hline Caucasians & 200 & $\begin{array}{l}38 \\
93\end{array}$ & $\begin{array}{l}39 \\
93\end{array}$ & $\begin{array}{l}1.08(0.85-1.38) \\
0.98(0.62-1.55)\end{array}$ & $\begin{array}{l}0.53^{*} \\
0.92 *\end{array}$ & \\
\hline Japanese & $\begin{array}{l}177 \\
172\end{array}$ & $\begin{array}{l}95 \\
38 \\
74\end{array}$ & $\begin{array}{l}95 \\
37 \\
72\end{array}$ & $\begin{array}{l}1.03(0.52-2.03) \\
0.95(0.70-1.29) \\
0.91(0.65-1.27)\end{array}$ & $\begin{array}{l}0.92^{+} \\
0.75^{+} \\
0.61^{+}\end{array}$ & (Horikawa et al., 2003) \\
\hline Mexican & 134 & 68.8 & 67.9 & $0.97(0.66-1.42)$ & $0.87 *$ & (del Bosque-Plata et al., 2004) \\
\hline mestizo & 114 & $\begin{array}{r}39 \\
77.3\end{array}$ & $\begin{array}{l}38.4 \\
74.3\end{array}$ & $\begin{array}{l}0.97(0.68-1.40) \\
0.85(0.56-1.29)\end{array}$ & $\begin{array}{l}0.88^{*} \\
0.45^{*}\end{array}$ & \\
\hline West Africa & $\begin{array}{l}347 \\
148\end{array}$ & $\begin{array}{l}85 \\
46\end{array}$ & $\begin{array}{l}86 \\
45\end{array}$ & $\begin{array}{l}1.10(0.74-1.62) \\
0.96(0.73-1.26)\end{array}$ & $\begin{array}{l}0.72^{+} \\
0.82^{+}\end{array}$ & $\left(\right.$Chen et al., 2005) ${ }^{\mathrm{b}}$ \\
\hline Korean & $\begin{array}{l}454 \\
236\end{array}$ & $\begin{array}{l}91.3 \\
36.5 \\
71.3\end{array}$ & $\begin{array}{l}91.1 \\
31.6 \\
66.9\end{array}$ & $\begin{array}{l}0.98(0.66-1.44) \\
0.80(0.64-1.02) \\
0.82(0.64-1.04)\end{array}$ & $\begin{array}{l}0.90^{*} \\
0.07 * \\
0.10^{*}\end{array}$ & (Kang et al., 2006) \\
\hline Northern China & $\begin{array}{l}493 \\
553\end{array}$ & $\begin{array}{r}89.8 \\
32.5 \\
80\end{array}$ & $\begin{array}{l}89.1 \\
34.3 \\
77.1\end{array}$ & $\begin{array}{l}0.93(0.70-1.23) \\
1.09(0.90-1.30) \\
0.84(0.68-1.04)\end{array}$ & $\begin{array}{l}0.61 * \\
0.38^{*} \\
0.11^{*}\end{array}$ & (Chen et al., 2007) \\
\hline Tunisian & $\begin{array}{l}917 \\
748\end{array}$ & $\begin{array}{l}91.2 \\
46.4 \\
83.8\end{array}$ & $\begin{array}{r}89.9 \\
40.4 \\
83\end{array}$ & $\begin{array}{l}0.86(0.68-1.08) \\
0.78(0.68-0.90) \\
0.95(0.79-1.14)\end{array}$ & $\begin{array}{l}0.20^{*} \\
0.001^{*} \\
0.54^{*}\end{array}$ & (Ezzidi et al., 2010)** \\
\hline Eastern Indians & $\begin{array}{l}200 \\
100\end{array}$ & $\begin{array}{l}80.5 \\
44.2 \\
91.2\end{array}$ & $\begin{array}{r}81 \\
40 \\
97.5\end{array}$ & $\begin{array}{l}0.97(0.63-1.49) \\
0.84(0.59-1.19) \\
3.74(1.44-9.69)\end{array}$ & $\begin{array}{l}0.83 \\
0.34 \\
0.003\end{array}$ & (Adak et al., 2010) \\
\hline Southern Indians & $\begin{array}{l}649 \\
794\end{array}$ & $\begin{array}{r}98 \\
44.4 \\
92.3\end{array}$ & $\begin{array}{r}98 \\
44.5 \\
90.8\end{array}$ & $\begin{array}{l}1.05(0.62-1.77) \\
1.01(0.87-1.17) \\
0.86(0.59-1.25)\end{array}$ & $\begin{array}{l}0.94 \\
0.94 \\
0.45\end{array}$ & (Bodhini et al., 2011) \\
\hline Mexican mestizo & $\begin{array}{l}211 \\
152\end{array}$ & $\begin{array}{l}72 \\
39 \\
83\end{array}$ & $\begin{array}{l}70 \\
32 \\
87\end{array}$ & $\begin{array}{l}0.91(0.66-1.26) \\
0.75(0.55-1.02) \\
1.35(0.89-2.06)\end{array}$ & $\begin{array}{l}0.56 \\
0.06 \\
0.16\end{array}$ & This study \\
\hline
\end{tabular}

N1 and N2. Cases and controls, respectively. Allele frequencies of SNP-43, SNP-19, and SNP-63 are ordered in row, consecutively. Note: Only allele 1 frequencies are reported. For OR estimation, alleles 1 were taken as reference. * Estimated OR of genotype frequencies reported by the authors. ${ }^{+}$Estimated OR of allele frequencies reported

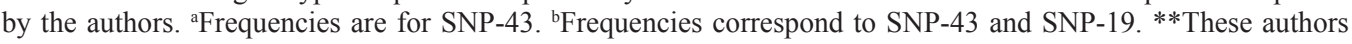
considered the allele $3 \mathrm{R}$ as allele 1 (To uniform our analysis we here change it, according to Horikawa et al., 2000). 
Although the patients had higher BMI than controls in our analysis, the polymorphisms analyzed showed not significant relationship with obesity, as revealed by comparing patients with BMI $<30 \mathrm{~kg} / \mathrm{m}^{2}$ and patients with BMI $\geq 30 \mathrm{~kg} / \mathrm{m}^{2}$. However, SNP-63 TT homozygotes showed an OR of $4.65(0.53-40.83 ; \mathrm{P}=0.13)$, suggesting a strong influence of this genotype on obesity and T2DM. Shima et al. (2003) also did not observe an association between these polymorphisms and higher BMI in a Japanese population using the wild-type genotype as a reference $(\mathrm{P}>0.05, \mathrm{P}=0.11$, and $\mathrm{P}=0.38$, for SNP-43, SNP-19, and SNP-63, respectively).

Analysis of a combination of polymorphisms showed that no haplotype was associated with T2DM risk. Because the 122 (G-3R-T) haplotype was predominantly present in the control group $(\mathrm{P}=0.006)$, it is associated with a protective effect against T2DM. However, this combination has not been reported as a protector haplotype in other series (Tsai et al., 2001; Malecki et al. 2002; Rasmussen et al., 2002; Horikawa et al., 2003; del Bosque-Plata et al., 2004; Wu et al., 2005; Kang et al., 2006; Adak et al., 2010; Ezzidi et al., 2010). Instead, in Eastern Indians, the 112 haplotype was related to an increased risk of T2DM [OR $=3.96$ (1.34-11.72); $\mathrm{P}=0.0079]$, whereas the 121 haplotype was related to a protector effect when compared with the remaining haplotypes that were pooled into a single group [OR $=0.70$ (0.50-0.99); $\mathrm{P}=0.05]$ (Adak et al., 2010). In Tunisia, the 112 haplotype (described by the authors as 122 because they used the 3R allele as allele 1) was not associated with T2DM (P $=0.115$ ), whereas the 121 haplotype (reported by the authors as 111) appeared to increase the risk of T2DM [OR = 1.22 (1.06-1.41); $\mathrm{P}=0.006]$ (Ezzidi et al., 2010). Note that to effectively compare our analysis to previous studies, we considered the $2 \mathrm{R}$ allele as allele 1 , according to Horikawa et al. (2000). In addition, the 111 haplotype was associated with an increased risk of T2DM in Koreans $(\mathrm{P}<0.0042)$ (Kang et al., 2006).

In discordance with Horikawa et al. (2000), who related the 112/121 diplotype with T2DM in Mexican-American patients, no diplotypes showed an association with T2DM in our study; indeed, this finding is consistent with most studies conducted worldwide (Tsai et al., 2001; Fingerlin et al., 2002; Malecki et al., 2002; Rasmussen et al., 2002; Horikawa et al., 2003; del Bosque-Plata et al., 2004; Wu et al., 2005; Kang et al., 2006; Kifagi et al., 2008; Adak et al., 2010; Ezzidi et al., 2010). Instead, the 112/121 diplotype was associated with lower BMI $(\mathrm{P}=0.016)$, decreased glycated hemoglobin $(\mathrm{P}=0.008)$, and increased high-density lipoprotein levels $(\mathrm{P}=0.034)$ in Japanese T2DM patients (Shima et al., 2003). Furthermore, surveys carried out on diverse racial groups have yielded inconsistent results; diplotypes associated with increased risk of T2DM include combinations 112/121 (Horikawa et al., 2000; Tsuchiya et al., 2006), 121/121 (Malecki et al., 2002; Tsuchiya et al., 2006), 111/121 (Kang et al., 2006), 112/221 (Wu et al., 2005; Adak et al., 2010), 121/221 (Kifagi et al., 2008), and 111/112 (Adak et al., 2010), whereas diplotypes related to a protector effect are 112/221 (Wu et al., 2005), 111/221 (Tsuchiya et al., 2006) and 121/121 (Kang et al., 2006).

Discordances observed for individual polymorphisms, haplotypes, or diplotypes among these diverse studies may be related to differences in sample size, statistical analyses, or selection criteria. However, these discrepancies could also be related to the specific genetic background of the racial groups analyzed. Moreover, as T2DM is a polygenic and multifactorial disease, susceptibility to this disease may be strengthened not only by single polymorphisms, haplotypes, or diplotypes in multiple genes, but also by obesity, lipid profile, poor nutrition, sedentary lifestyle, gender, and other factors (American Diabetes Association, 2013). Hence, future studies should analyze larger samples, consider interracial variations, and 
adjust covariates associated with $\mathrm{T} 2 \mathrm{DM}$ to obtain more reliable results regarding the role of polymorphisms, haplotypes, or diplotypes of CAPN10 in T2DM risk.

In conclusion, none of the alleles, genotypes, haplotypes or diplotypes of the 3 polymorphisms analyzed of CAPN10 were significantly associated with T2DM in our sample of Mexican mestizos, which may be because of the small sample size; thus, further studies should examine the role of CAPN10 risk alleles in T2DM populations.

\section{ACKNOWLEDGMENTS}

Research supported by Universidad Autónoma de Tamaulipas through grant UAT10SAL-0509 and by Universidad Autónoma de Sinaloa (\#grant PROFAPI2010-UAS-100). We thank Dr. H. Rivera for the critical review of the manuscript.

\section{REFERENCES}

Adak S, Sengupta S, Chowdhury S and Bhattacharyya M. (2010). Co-existence of risk and protective haplotypes of Calpain 10 gene to type 2 diabetes in the eastern Indian population. Diab Vasc. Dis. Res. 7: 63-68.

American Diabetes Association. (2013). Standards of medical care in diabetes - 2103. Diabetes Care 36: S11-S66.

Bodhini D, Radha V, Ghosh S, Sanapala KR, et al. (2011). Association of calpain 10 gene polymorphisms with type 2 diabetes mellitus in Southern Indians. Metabolism 60: 681-688.

Chen SF, Lu XF, Yan WL, Guang JF, et al. (2007). Variations in the calpain-10 gene are associated with the risk of type 2 diabetes and hypertension in northern Han Chinese population. Chin. Med. J. 120: 2218-2223.

Chen Y, Kittles R, Zhou J, Chen G, et al. (2005). Calpain-10 gene polymorphisms and type 2 diabetes in West Africans: the Africa America Diabetes Mellitus (AADM) Study. Ann. Epidemiol. 15: 153-159.

del Bosque-Plata L, Aguilar-Salinas CA, Tusié-Luna MT, Ramírez-Jiménez S, et al. (2004). Association of the calpain-10 gene with type 2 diabetes mellitus in a Mexican population. Mol. Genet. Metab. 81: 122-126.

Evans JC, Frayling TM, Cassell PG, Saker PJ, et al. (2001). Studies of association between the gene for calpain-10 and type 2 diabetes mellitus in the United Kingdom. Am. J. Hum. Genet. 69: 544-552.

Ezzidi I, Turki A, Messaoudi S, Chaieb M, et al. (2010). Common polymorphism of calpain-10 and the risk of type 2 diabetes in a Tunisian Arab population: a case-control study. BMC Med. Genet. 11: 75-82.

Fingerlin TE, Erdos MR, Watanabe RM, Wiles KR, et al. (2002). Variation in three single nucleotide polymorphisms in the calpain-10 gene not associated with type 2 diabetes in a large Finnish cohort. Diabetes 51: 1644-1648.

Garant MJ, Kao WH, Brancati F, Coresh J, et al. (2002). SNP43 of CAPN10 and the risk of type 2 Diabetes in AfricanAmericans: the Atherosclerosis Risk in Communities Study. Diabetes 51: 231-237.

Haddad L, Evans JC, Gharani N, Robertson C, et al. (2002). Variation within the type 2 diabetes susceptibility gene calpain-10 and polycystic ovary syndrome. J. Clin. Endocrinol. Metab. 87: 2606-2610.

Horikawa Y, Oda N, Cox NJ, Li X, et al. (2000). Genetic variation in the gene encoding calpain-10 is associated with type 2 diabetes mellitus. Nat. Genet. 26: 163-175.

Horikawa Y, Oda N, Yu L, Imamura S, et al. (2003). Genetic variations in calpain-10 gene are not a major factor in the occurrence of type 2 diabetes in Japanese. J. Clin. Endocrinol. Metab. 88: 244-247.

International Diabetes Federation. Diabetes: Protect our future. http://www.idf.org/worlddiabetesday/2013. Accessed November 8, 2013.

Kang ES, Kim HJ, Nam M, Nam CM, et al. (2006). A novel 111/121 diplotype in the calpain-10 gene is associated with type 2 diabetes. J. Hum. Genet. 51: 629-633.

Kifagi C, Makni K, Mnif F, Boudawara M, et al. (2008). Association of calpain-10 polymorphisms with type 2 diabetes in the Tunisian population. Diabetes Metab. 34: 273-278.

Lynn S, Evans JC, White C, Frayling TM, et al. (2002). Variation in the calpain-10 gene affects blood glucose levels in the British population. Diabetes 51:247-250.

Malecki MT, Moczulski DK, Klupa T, Wanic K, et al. (2002). Homozygous combination of calpain 10 gene haplotypes is associated with type 2 diabetes mellitus in a Polish population. Eur. J. Endocrinol. 146: 695-699.

OMIM: Online Mendelian Inheritance in Man. http://www.ncbi.nlm.nih.gov/entrez/dispomim.cgi?id=125853. Accessed August 21, 2013.

Orho-Melander M, Klannemark M, Svensson MK, Ridderstrale M, et al. (2002). Variants in the calpain-10 gene predispose 
to insulin resistance and elevated free fatty acid levels. Diabetes 51: 2658-2664.

Patel YM and Lane MD (1999). Role of calpain in adipocyte differentiation. Proc. Natl. Acad. Sci. U. S. A. 96: 1279-1284.

Rasmussen SK, Urhammer SA, Berglund L, Jensen JN, et al. (2002). Variants within the calpain-10 gene on chromosome 2q37 (NIDDM1) and relationships to type 2 diabetes, insulin resistance, and impaired acute insulin secretion among Scandinavian Caucasians. Diabetes 51: 3561-3567.

Sáez M, González-Sánchez J, Ramírez-Lorca R, Martínez-Larrad MT, et al. (2008). The CAPN10 Gene is associated with insulin resistance phenotypes in the Spanish population. PLoS One 3: e2953-e2960.

Shima Y, Nakanishi K, Odawara M, Kobayashi T, et al. (2003). Association of the SNP-19 genotype 22 in the calpain-10 gene with elevated body mass index and hemoglobin A1c levels in Japanese. Clin. Chim. Acta 336: 89-96.

Tsai HJ, Sun G, Weeks DE, Kaushal R, et al. (2001). Type 2 diabetes and three calpain-10 gene polymorphisms in Samoans: no evidence of association. Am. J. Hum. Genet. 69: 1236-1244.

Tsuchiya T, Schwarz PE, del Bosque-Plata L, Geoffrey Hayes M, et al. (2006). Association of the calpain-10 gene with type 2 diabetes in Europeans: results of pooled and meta-analyses. Mol. Genet. Metab. 89: 174-184.

Villalpando S, de la Cruz V, Rojas R, Shamah-Levy T, et al. (2010). Prevalence and distribution of type 2 diabetes mellitus in Mexican adult population. a probabilistic survey. Salud Pública Mex. 52: S19-26.

Wu B, Takahashia J, Fub M, Cheng H, et al. (2005). Variants of calpain-10 gene and its association with type 2 diabetes mellitus in a Chinese population. Diabetes Res. Clin. Pract. 68: 155-161. 